У ДК 004.9.005.95

Анатолій Рибидайло, кандидат технічних наук, старший науковий співробітник ORCID ID 0000-0002-6156-469X

Тетяна Уварова, кандидат технічних наук ORCID ID 0000-0003-2388-4059 Сергій Горбачевський, кандидат технічних наук, старший науковий співробітник ORCID ID 0000-0002-4946-1604

Ірина Цимбал, ORCID ID 0000-0001-7294-3794

Андрій Мулявка,

ORCID ID 0000-0002-3113-0719 Національний університет оборони України імені Івана Черняховського DOI: 10.33099/2617-1775/2021-02/205-220

\title{
АНАЛІЗ ДОСВІДУ РОБОТИ ВІДБІРКОВИХ КОМІСІЙ У ЗБРОЙНИХ СИЛАХ КРАЇН НАТО І ЄС: ЗАВДАННЯ, ФУНКЦІЇ ТА ПОРЯДОК ВІДБОРУ
}

Стаття присвячена питанням роботи відбіркових комісій у збройних силах країн НАТО $і$ СС з метою використання набутого досвіду для впровадження у практичну діяльність кадрових органів Збройних Сил Украӥни. Наведена загальна структура управління людськими ресурсами, яка застосовується у будь-якій армї окремої держави. У прочедурах навчання (підвищення кваліфікаџіï) та просування по службі беруть участь комісї (приймальні, відбіркові, атестаційні), які формують певні рекомендації особам, щзо приймають кадрові рімення.

Досліджено порядок просування по службі особового складу держав, які входять до складу ЄС і НАТО та проаналізовано особливості застосування приймальних, відбіркових, атестаційних комісій.

Ключові слова: приймальні; атестачійні; відбіркові комісї; менеджмент людських ресурсів; стратегічне управління людськими ресурсами; підготовка $i$ просування персоналу збройних сил.

Постановка проблеми. Метою системи кадрового менеджменту у сфері оборони є забезпечення наявності на потрібних посадах і позиціях потрібної кількості людей $з$ потрібним набором професійних навичок та досвідом для вирішення завдань оборони - тобто участі у військових операціях, розвитку оборонних спроможностей для вирішення майбутніх завдань, здійснення функцій управління й командування і таке інше.

Система кадрового менеджменту збройних сил працюватиме ефективно, якщо вона буде виконувати дві взаємопов'язані функції, які доповнюють одна 
одну: визначення кадрової потреби визначеної кваліфікації та розвиток персоналу збройних сил.

1. Визначення потреби в людських ресурсах, виходячи 3 існуючих i перспективних оборонних потреб та планів розвитку сил і засобів передбачає обгрунтування короткострокових потреб для підтримки існуючого рівня i структури збройних сил, середньострокових (5-6 років) потреб для забезпечення розвитку збройних сил i, нарешті, довгострокових (15 або більше років) відповідно до визначених стратегічних параметрів розвитку збройних сил.

2. Менеджмент та розвиток людських ресурсів, як на рівні окремого представника збройних сил, так і військової організації в цілому, 3 метою максимального підвищення потенціалу людських ресурсів відповідно до оборонних потреб. Це вимагає постійної системної роботи із залучення на військову службу, освіти та підготовки, мотивації, призначення на посади, присвоєння чергових військових звань i втримання на військовій службі необхідної кількості особового складу потрібної професійної кваліфікації (тобто з потрібними знаннями, навичками та досвідом).

На рис. 1 наведена загальна структура управління людськими ресурсами, яка застосовується у будь-якій армії окремої держави [1]. Відмінності містяться в процедурах набору, навчання i просування по службі, які обумовлені наступними факторами:

- географічне розташування держави (вихід до моря, наявність агресивного сусіда тощо);

- участь держави в організації колективного захисту (воєнні блоки);

- стан економічного розвитку і наявність людських ресурсів;

- менталітет населення, який обумовлено історичними традиціями;

- нормативна і законодавча база.

У процедурах навчання (підвищення кваліфікації) та просування по службі беруть участь комісії (приймальні, відбіркові, атестаційні), які формують певні рекомендації особам, що приймають кадрові рішення. Отже, доцільно розглянути досвід використання означених комісій в збройних силах інших країн для надання обгрунтованих рекомендацій стосовно його застосування в освітньо-професійному розвитку офіцерів ЗС України.

Довідка. Комісія - група осіб або орган, що формується в складі групи осіб для виконання будь-яких конкретних функцій або проведення спеціальних заходів.

Приймальна комісія закладу вищої освіти (англ. University admission or college admission) - робочий орган закладу вищої освіти, що утворюється для організації прийому вступників. Строк повноважень Приймальної комісії становить один календарний рік.

Відбіркова комісія 3 відбору кандидатів до призначення на посади $\epsilon$ дорадчим органом, що здійснює вивчення військовослужбовців, які включенні до резерву кандидатів для просування по службі та відібранні кандидатами для призначення на конкретну вакантну посаду.

Атестаційна комісія - постійно діючий дорадчий орган, що створюється 
для всебічної оцінки виконання службових обов'язків військовослужбовців за контрактом, вдосконалення роботи щодо їх добору, вивчення та розподілу, мобілізації на подальше підвищення професійного рівня (кваліфікації), зміцнення дисципліни.

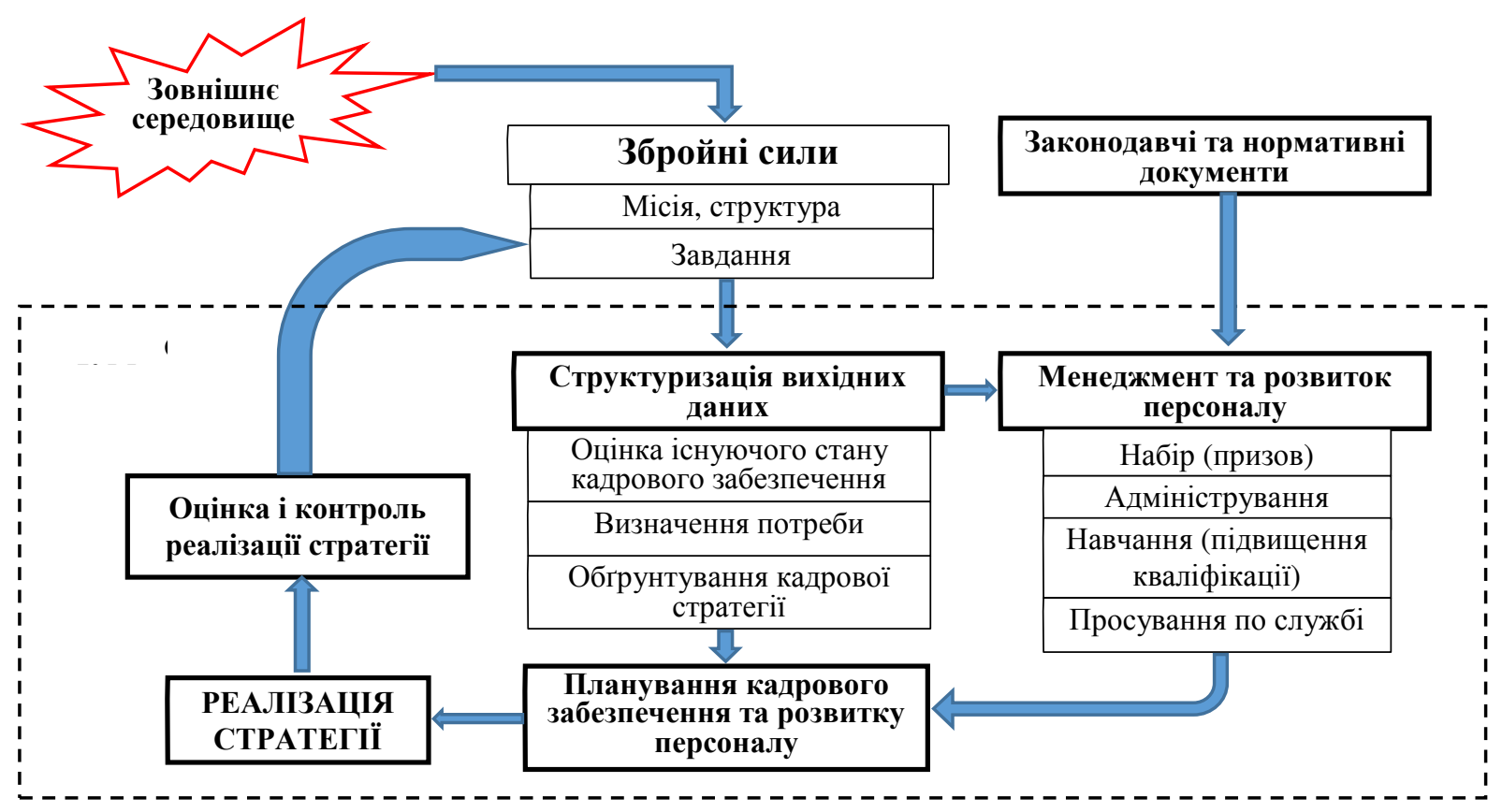

Рис. 1 Структура стратегічного управління людськими

Аналіз останніх досліджень і публікацій. У відкритих джерелах достатня кількість робіт, наприклад [2-7], присвячених вирішенню питань підвищення якості військової підготовки регулярних військ і резерву, а також способам комплектування збройних сил особовим складом в періоди криз та загострення політичної обстановки в регіоні. Розглядаються принципи формування збройних сил: професійно добровільний; міліційний і міліційно-кадровий; кадрово-призовний. Крім того розглянуті територіальний і екстериторіальний способи формування збройних сил.

У джерелах [3-11] висвітлені особливості підготовки і просування офіцерів у збройних силах США, Німеччини, Великобританії та Ізраїлю.

Проте, аналіз наукової літератури свідчить про приділення недостатньої уваги порушеному питанню, що може призвести до уповільнення процесів професійного зростання, та наближення ЗС України до стандартів НАТО.

Мета статті - аналіз порядку просування по службі особового складу у збройних силах держав, які входять до складу $Є \mathrm{C}$ i HАTO та досвіду використання відбіркових комісій у цьому процесі для надання обгрунтованих рекомендацій щодо освітньо-професійний розвитку офіцерського складу ЗС України.

Виклад основного матеріалу. Проблема якісної підготовки офіцерських кадрів $\epsilon$ однією 3 основних серед проблем підтримання високої бойової готовності частин і підрозділів, оскільки офіцер є центральною фігурою в здійсненні бойової підготовки особового складу, забезпечення правильної 
експлуатації і збереження техніки і озброєння. Ні у кого не викликає сумніву те, що офіцер є професіоналом в повному розумінні цього поняття. Сьогодні жодна армія не може існувати без офіцерів, і тим більше, якщо ця армія комплектується на контрактній основі. Тому практично всі держави світу піклуються про вдосконалення системи підготовки офіцерських кадрів.

Найбільш поширеною концепцією підготовки офіцерських кадрів $\epsilon$ концепція постійного вдосконалення професійного вишколу і безперервного навчання офіцерів. Суть цієї концепції полягає в тому, що протягом усього свого служби офіцер проходить через багаторівневу систему підготовки та перепідготовки, що дозволяє йому не тільки зберігати отримані на початковому етапі знання і навички, а й розвивати і вдосконалювати їх.

Підготовка офріцерських кадрів у ЗС США. В даний час більшість міжнародних конфліктів не обходиться без використання військової сили США, які прагнуть зміцнити лідируюче положення в світі шляхом зміцнення своєї військової могутності. Для досягнення даної мети американське військовополітичне керівництво велику увагу приділяє питанням комплектування ЗС високопрофесійними фахівцями, перш за все офіцерськими кадрами. Цією проблемою займаються безпосередньо командування міністерств видів збройних сил. Ці структури визначають поточні та перспективні потреби в офіцерському складі, розробляють щорічні та довгострокові плани по набору курсантів і слухачів до навчальних закладів, через підпорядковані органи організовують їх відбір, перевірку та зарахування. Їх діяльність координується управлінням помічника міністра оборони з особового складу. В цілому систему підготовки офіцерських кадрів з різних спеціальностей для американських $3 \mathrm{C}$ можна структурно розділити на три основні підсистеми [2]:

- військові навчальні заклади МО;

- курси позавійськової підготовки офіцерів резерву ROTC (Reserve Officers Training Corps) при цивільних вузах [3];

- прямий набір цивільних осіб на офіцерські посади.

Щорічне поповнення офіцерського корпусу ВС США в останнє десятиліття більш ніж наполовину забезпечується за рахунок випускників військових навчальних закладів та близько 40\% за рахунок курсів ROTC при цивільних вузах. Прямий набір кадрів на офіцерські посади в ЗС США з числа цивільних осіб вельми незначний і здійснюється за спеціальними програмами. Це стосується перш за все таких категорій цивільних осіб, як лікарі, військові капелани, а також фахівці деяких досить рідкісних технічних спеціальностей.

Структура системи підготовки офіцерських кадрів для ЗС США представлена на рис. 2. 


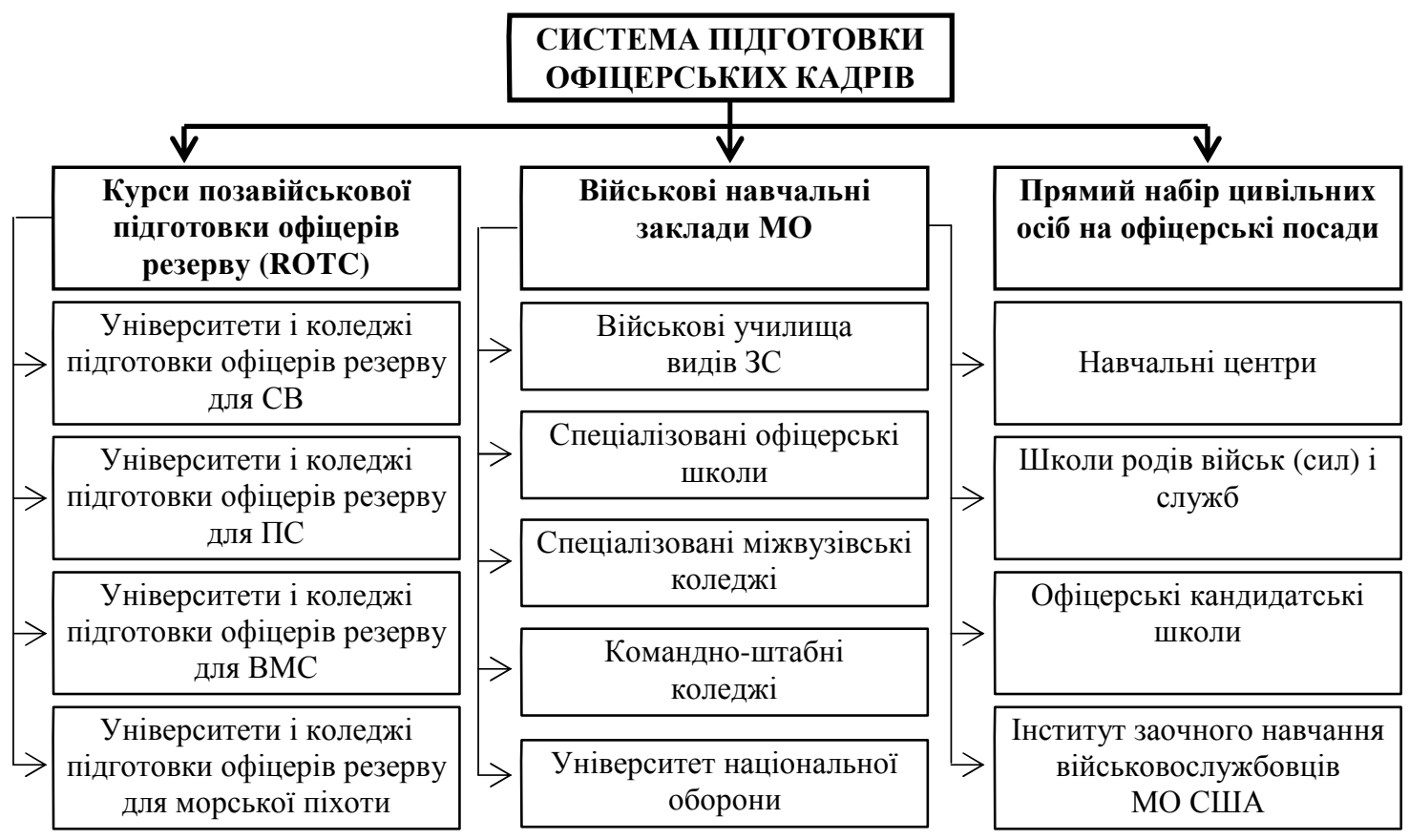

Рис. 2 - Структура системи підготовки офіцерських кадрів для 3С

Всі навчальні програми професійної освіти відповідно до їх спеціалізації підрозділяються на 13 галузей. Спеціальність "військові науки" відноситься до наукової галузі. Галузь "природні і технічні науки" включає "інженерні науки", “комп'ютерні та інформаційні науки” і “фізичні науки”.

Навчальні заклади, що займаються підготовкою i підвищенням загальноосвітньої і військово-спеціальної кваліфікації офіцерів, мають певні характеристики, відповідно до яких їх можна поділити на військові навчальні заклади, які здійснюють:

- вищу професійну загальноосвітню і базову військову підготовку;

- перепідготовку або додаткову поглиблену професійну загальноосвітню i/або військово-спеціальну підготовку;

- підвищення військової кваліфікації; підвищення рівня загальноосвітньої, спеціальної та професійної підготовки; вищу військову підготовку.

В цивільних навчальних закладах, що мають курси ROTC, проводиться вища спеціальна загальноосвітня і загальна військова підготовка.

У військових училищах (за американською термінологією академіях) видів 3С проводиться базова підготовка офіцерів. Випускники отримують вищу загальну освіту і диплом бакалавра, середнє освіту і первинне офіцерське звання другий лейтенант (в ВМС ен-сайн, категорія 0-1), яке присвоюється міністрами видів збройних сил.

У спеціалізованих міжвидових коледжах і військових школах офіцери проходять перепідготовку або додаткову поглиблену підготовку за обраною спеціальністю i здобувають вищу військово-спеціальну освіту i диплом магістра. Назва "школа" данина традиції, а не показник отриманої освіти. За своїм статусом ці навчальні заклади можна порівняти 3 цивільними університетами. Наприклад, у військово-морській школі в м. Монтеррей близько 50 факультетів, більшість викладачів мають тривалий досвід роботи в 
провідних університетах країни і більше половини педагогічну діяльність поєднують зі служінням науці в прославленому Стенфордському (Каліфорнійському) університеті, що знаходиться поблизу від школи.

Місцем перепідготовки та підвищення військової кваліфікації офіцерів (без присудження більш високого ступеня загальної освіти) $\epsilon$, крім того, курси перепідготовки та удосконалення, що функціонують при навчальних центрах $\mathrm{i}$ школах родів військ (сил) і служб.

Первинне офіцерське звання присвоюється також військовослужбовцям, які закінчили офіцерські кандидатські школи (сухопутних військ і морської піхоти) i школу підготовки офіцерів ВПС. Слухачами офіцерських кандидатських шкіл (мають статус курсів, після закінчення яких присуджується ступінь молодшого спеціаліста) стають в основному сержанти і рядові регулярних військ. В школу підготовки офіцерів ВПС набираються особи, які закінчили повний курс цивільного коледжу або університету, що мають необхідну авіаційну підготовку і ступінь загальної освіти не нижче бакалавра.

У військових командно-штабних коледжах видів 3С i Університеті національної оборони старші офіцери здобувають вищу військову освіту i диплом магістра, в окремих випадках доктора.

Найбільш відомим військово-навчальним закладом США з підготовки кадрових військових для сухопутних військ $\epsilon$ академія Вест-Пойнт, яка утворена в 1802 році президентом Джефферсоном. В даний час Вест-Пойнт найбільш престижний військовий навчальний заклад США. Туди приймаються громадяни США у віці від 17 до 22 років, які не перебувають у шлюбі і не мають на утриманні дітей. Академія використовує систему реєстрації претендентів за попередніми заявами, відповідно до чого приймальна комісія надсилає претенденту анкету, яка заповнюється і повертається до приймальної комісії разом з атестатом про освіту (для оформлення особової справи).

Вступники до Вест-Пойнт проходять систему рекомендацій, оцінки та відбору. Рекомендація $\epsilon$ юридичним документом для розгляду приймальною комісією академії ділових якостей вступника. Ї̈̈ можуть давати особи, уповноважені конгресом. У тому числі: Віце-президент, Сенатори, члени палати представників, губернатори територіальних володінь (Пуерто-Ріко, Східне Самоа), Представники в конгресі від округу Колумбія, від Віргінських островів, від острова Гуам.

Система професійного відбору майбутніх офіцерів існує і в військових навчальних закладах інших країн. Наприклад, кандидати на навчання в Королівському коледжі Канади, створеного за розпорядженням канадського парламенту в 1876 році, повинні також пройти спеціальний відбір. Цей відбір включає: психологічні тести, співбесіду і медичний огляд.

Аналогічний відбір існує і в військових навчальних закладів Туреччини. Кандидат для навчання у військовому навчальному закладі Туреччини перед вступними іспитами повинен пройти не тільки медичну комісію, а й співбесіду. Співбесіда передбачає оцінку політичної благонадійності, духовного і культурного рівня.

Таким чином у Збройних силах США існують три основні рівні підготовки 
офіцерів, які відрізняються один від одного об’ємом знань і навичок, якими повинен володіти офіцер після завершення курсу навчання на тому чи іншому рівні підготовки (рис. 3).

Після першого рівня навчання офіцер повинен володіти знаннями необхідними для виконання обов'язків до командира батальйону і рівних йому підрозділів включно. При цьому термін навчання в вищих військовонавчальних закладах становить не менше 4-х років. Однак навіть після цього випускник повинен перед призначенням на первинну посаду пройти спеціалізацію (4-8 тижнів).

На другому рівні здійснюється підготовка офіцерів для ланки батальйон, бригада, дивізія і їм рівні частини і з'єднання. При цьому офіцер повинен володіти вислугою від 10 до 15 років. Термін навчання 5-10 місяців.

Третій рівень підготовки включає військово-навчальні заклади для підготовки офіцерів (генералів, адміралів) з вищою військовою підготовкою для ланки “дивізія-корпус-об'єднане (центральне) командування”, а також офіцерів (генералів, адміралів) для роботи в центральному апараті міністерства оборони і видів збройних сил. Термін навчання 10 місяців.

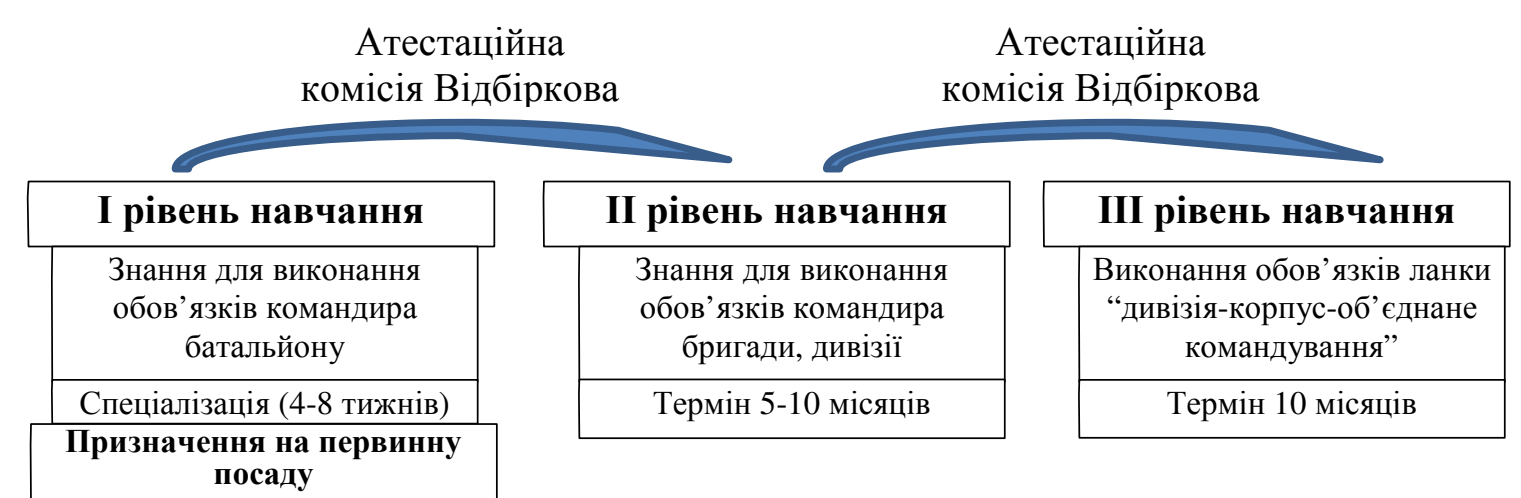

Рис. 3. Рівні підготовки офіцерів Збройних сил США

Аналогічна система багаторівневої підготовки існує і в Англії, а в ЗС Німеччини система підготовки має ще більш складну багаторівневу структуру.

Підготовка офіцерських кадрів у Німеччині. Офіцерський склад бундесверу представлений кадровими офіцерами і офіцерами, які проходять службу за контрактом (на 3-15 років і два роки). Структурно-логічна модель безперервної багатоступінчастої професійної підготовки офіцерів бундесверу представлена на рис. 4. 


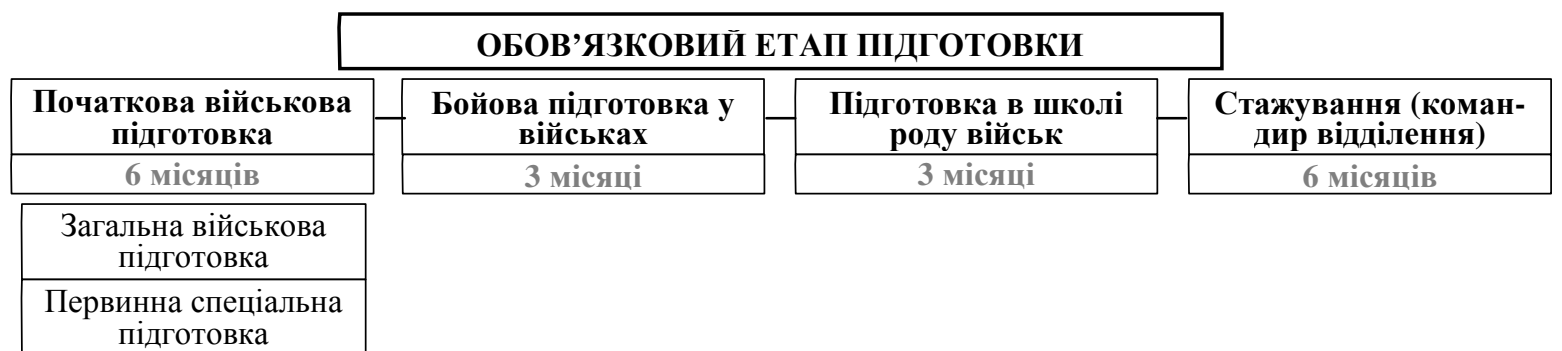

ПІДГОТОВКИ ОФІЦЕРІВ ЗА КОНТРАКТОМ НА 3-4 РОКИ

\begin{tabular}{|c|c|c|c|}
\hline Стажування у військах & $\begin{array}{c}\text { Курс офіцера } \\
\text { резервv }\end{array}$ & \begin{tabular}{|c|} 
Курс офіцера резерву в \\
школі роду військ
\end{tabular} & $\begin{array}{l}\text { Служба на посаді } \\
\text { командира взводу }\end{array}$ \\
\hline 5 місяців & 4 тижні & 8 тижнів & Закінчення контракту \\
\hline
\end{tabular}

ПІДГОТОВКИ ОФІЦЕРІВ ЗА КОНТРАКТОМ НА 3-11 РОКІВ

\begin{tabular}{|c|c|c|c|}
\hline Стажування у військах & $\begin{array}{l}\text { Курс в офіцерській } \\
\text { школі (іспит) }\end{array}$ & $\begin{array}{c}\text { Курс офіцера в школі } \\
\text { роду військ }\end{array}$ & $\begin{array}{l}\text { Служба на посаді } \\
\text { командира взводу }\end{array}$ \\
\hline 5 місяців & 5 місяців & 3 місяці & 11 місяців \\
\hline
\end{tabular}

ПІДГОТОВКИ ОФІЦЕРІВ ЗА КОНТРАКТОМ НА 12-15 РОКІВ

\begin{tabular}{|c|}
\hline $\begin{array}{c}\text { Стажування } \\
\text { військах }\end{array}$ \\
\hline 5 місящів \\
\hline
\end{tabular}

\begin{tabular}{|c|}
\hline $\begin{array}{c}\text { Курс в } \\
\text { офіцерській } \\
\text { школі (іспит) }\end{array}$ \\
\hline 5 місяців \\
\hline
\end{tabular}

\begin{tabular}{|c|}
\hline $\begin{array}{c}\text { Курс офіцера в } \\
\text { школі роду } \\
\text { військ }\end{array}$ \\
\hline 3 місящі \\
\hline
\end{tabular}

\begin{tabular}{|c|}
\hline $\begin{array}{c}\text { Служба на посаді } \\
\text { командира взводу }\end{array}$ \\
\hline 11 місящів \\
\hline
\end{tabular}

\begin{tabular}{|c|}
\hline $\begin{array}{c}\text { Навчання в } \\
\text { університеті } \\
\text { бундесверу }\end{array}$ \\
\hline До 4 років \\
\hline
\end{tabular}

Рис. 4. Модель професійної підготовки офіцерів ЗС Німеччини

Всі кандидати в офіцери проходять навчання за єдиною програмою, що включає наступні етапи [6]:

- початкова військова підготовка у військах за програмою рядового військовослужбовця (шість місяців), яка поділяється:

загальна початкова військова підготовка (три місяці) проходять всі кандидати в офіцери незалежно від приналежності до роду військ;

первинна спеціальна підготовка (три місяці) враховує специфіку відповідного роду військ;

- бойова підготовка у військах і навчання для отримання водійських прав (три місяці);

- курс підготовки для отримання військового звання фанен-юнкера в школі роду військ (відповідає рівню підготовки унтер-офіцерів) три місяці;

- стажування на посаді командира відділення свого роду військ три місяці (для кандидатів в офіцери за контрактом на три або чотири роки шість місяців).

Подальше навчання організовується відповідно до тривалості контракту на військову службу, а також 3 рівнем загальної та професійної підготовки кандидата в офіцери.

Ротація офіцерського складу на посадах здійснюється в середньому через три роки. При цьому, офіцер може або висуватись на вищу посаду, або обіймати іншу рівнозначну. Через 10 років проходження служби офіцер може бути направлений на курси підвищення кваліфікації, на 14 році служби тримісячні курси штабних офіцерів, через 15-16 років служби - має право поступати до академії ЗС, яка готує вищий командний склад для головних штабів (рис. 5). 


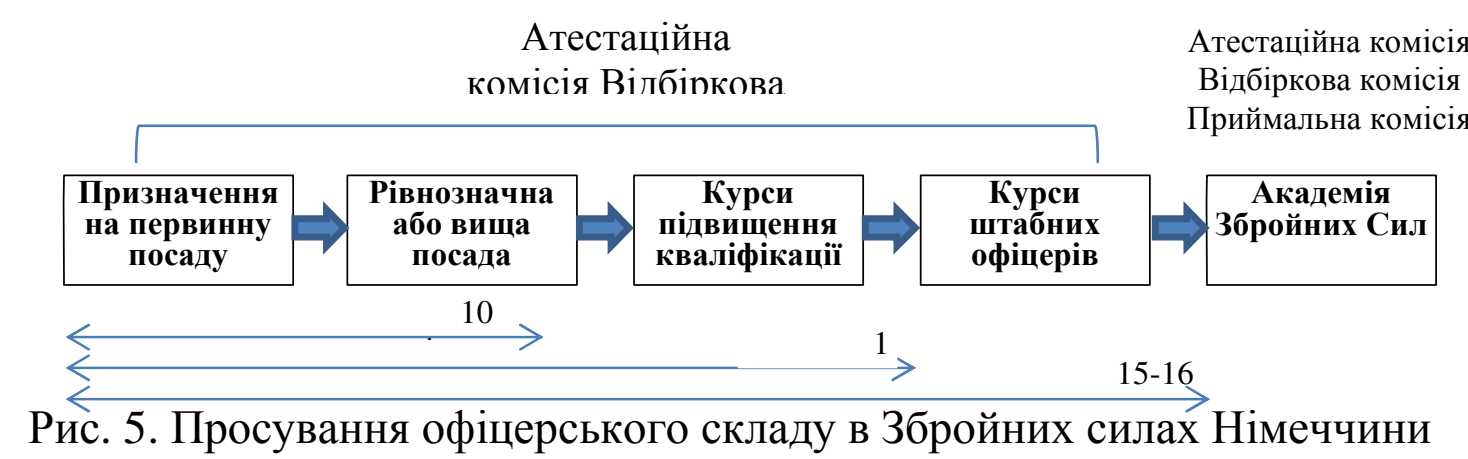

Франція. Збройні сили Французької Республіки 32002 року комплектуються повністю добровольцями. Призов у мирний час був скасований в 1996 році, проте юнаки, які народилися до 1979-го, повинні були завершити свою службу в рядах національних 3С. 27 липня 2001 року рішенням президента був виданий декрет, згідно з яким з 01 грудня 2001року республіка перейшла повністю до комплектування армії на добровільній основі. На даний момент в ЗС Франції налічується 250 тис. військовослужбовців.

На дійсну військову службу в якості добровольців приймаються громадяни у віці від 18 до 32 років, а на навчання для отримання військової спеціальності та в унтер-офіцерські школи - 317 років [8].

Контракти можуть продовжуватися рядовими протягом 15 років, унтерофіцерам - до граничного віку або при загальній вислузі 21 рік.

Офіцерський корпус Збройних сил Великобританії формується як за рахунок випускників військових училищ (кадровий офіцерський склад), так і за рахунок випускників цивільних вищих навчальних закладів, які вербуються за контрактами (склад короткострокової служби).

Для вступу на військову службу особи, які досягли встановленого віку, спочатку звертаються в письмовій або усній формі в інформаційний пункт або до офіцерів по зв'язку з цивільними навчальними закладами, отримують необхідні бланки і документи для заповнення, а також рекламну літературу. Крім того, для них організовується відвідування навчальних центрів родів військ (сил) і служб. Після цього вони направляються на відбіркову комісію (існує при кожному виді 3С), де проходять протягом трьох днів співбесіду, тести, військово-медичне обстеження і перевірку на фізичну витривалість. На підставі результатів тестування відбіркові комісії пропонують кандидатам рід військ (службу), укладають контракт i розподіляють їх до військових навчальних закладів та навчальні центри.

Процес підготовки до проходження служби за обраною спеціальністю включає три етапи:

- перший етап (тривалістю в середньому до 14 тижнів) передбачає вивчання основних дисциплін, необхідних кожному військовослужбовцю;

- метою другого emany є набуття професійних знань і навичок відповідно до фаху.

- протягом всього терміну служби в діючій армії військовослужбовці ЗС Великобританії періодично проходять перепідготовку (тривалість 
перепідготовки може досягати декількох місяців) в УЦ або на курсах при військовому коледжі у відповідності зі своєю спеціальністю або перед призначенням на іншу посаду (третій етап навчання).

В $\underline{\text { Iзрайлi }}$ створено одну з найефективніших систем підготовки армійських кадрів, яка охоплює всі верстви населення, починаючи зі шкільної лави.

Після досягнення 18-річного віку всі ізраїльтяни обох статей підлягають призову в армію. Військовозобов'язаними вважаються бездітні жінки i незаміжні до 26 років. Від обов'язкової служби можуть бути звільнені дівчата, дотримуються релігійні заповіді. Термін служби для жінок становить два роки. Загальним для всіх $є$ проходження курсу молодого бійця (тіронут), тривалість $\mathrm{i}$ складність якого залежать від роду військ, в який направляється призовник [11]. Всі військові спеціальності діляться на бойові, пов'язані з виконанням бойових завдань, і спеціальності тилового забезпечення.

Для солдатів бойових частин наступним етапом бойової підготовки $є$ курс просунутого навчання, який триває кілька місяців. Найбільш підготовлені бійці потім проходять курс сержантів, і лише найкращі випускники курсу сержантів можуть отримати направлення на офіцерські курси. Для визначення цих категорії використовуються атестаційні та відбіркові комісії. Таким чином, для кандидатів в офіцери $\epsilon$ обов'язковим проходження всіх етапів бойового навчання, яка проходить безпосередньо у військах і загальна тривалість іiі може досягати від одного до півтора років. Весь цей час солдат поєднує навчання 3 несенням служби в своїх військових частинах.

Навчання на офіцерських курсах, 3 огляду на їх короткостроковість, відрізняється високою інтенсивністю і вимагає від курсантів максимальних моральних i фізичних зусиль. Тих, хто не може справлятися 3 такими навантаженнями, чекає негайне відрахування з курсу. Вся система навчання нерозривно пов'язана з вирішенням реальних бойових завдань, значну частину часу курсанти проводять в полі і на навчаннях, де негайно закріплюються отримані теоретичні знання. Наголос робиться на оволодіння майбутніми офіцерами практичних навичок командування підрозділами. Вся виховна робота спрямована на підготовку офіцерів до усвідомленого і відповідального виконання покладених на них бойових завдань. Така система військової освіти в Ізраїлі охоплює практично все населення країни. За багато років воєн і збройних конфліктів вона довела свою ефективність і стала прикладом для армій інших держав. Система військової освіти Ізраїлю знаходиться в постійному розвитку і чуйно реагує на вимоги сучасної війни і державного будівництва.

Розглянемо особливості роботи відбіркових комісій на прикладі ЗС США.

За досвідом відбору військовослужбовців Сухопутних військ США для просування їх по службі з метою підвищення ефективності та якості відбору кандидатів на посади створюються відбіркові комісії.

Оцінювання результатів відбору є ключовою частиною відборів. Відбір здійснюють як керівники, так і призначені комісії.

Для підвищення якості роботи відбіркових комісій для визначення кращих кандидатів на посади спеціально для комісій розробляються рекомендації, які 
складаються з трьох розділів:

1. Загальні рекомендації: комісія створюється 3 метою визначення з числа кандидатів на посади тих офіцерів, які мають найвищу кваліфікацію для використання функцій вищого рівня.

2. Необхідні якості кандидатів - відданість службі на користь суспільства; здатність до лідерства; технічна та тактична кваліфікація; здатність забезпечувати розвиток i зростання підлеглих та створювати ефективні організаційні структури; широкий обсяг знань та досвіду; здатність до дій у різних ролях та організаційних структурах.

3. Комісія приймає оптимальне рішення, спираючись на свій досвід та оцінку особової справи кандидата на предмет його офіцерського потенціалу.

Система відбору враховує індивідуальні переваги військовослужбовців щодо характеру призначень, їх навчання і підготовки.

На рис. 6 показана загальна послідовність процесу відбору кандидатів на посаду.

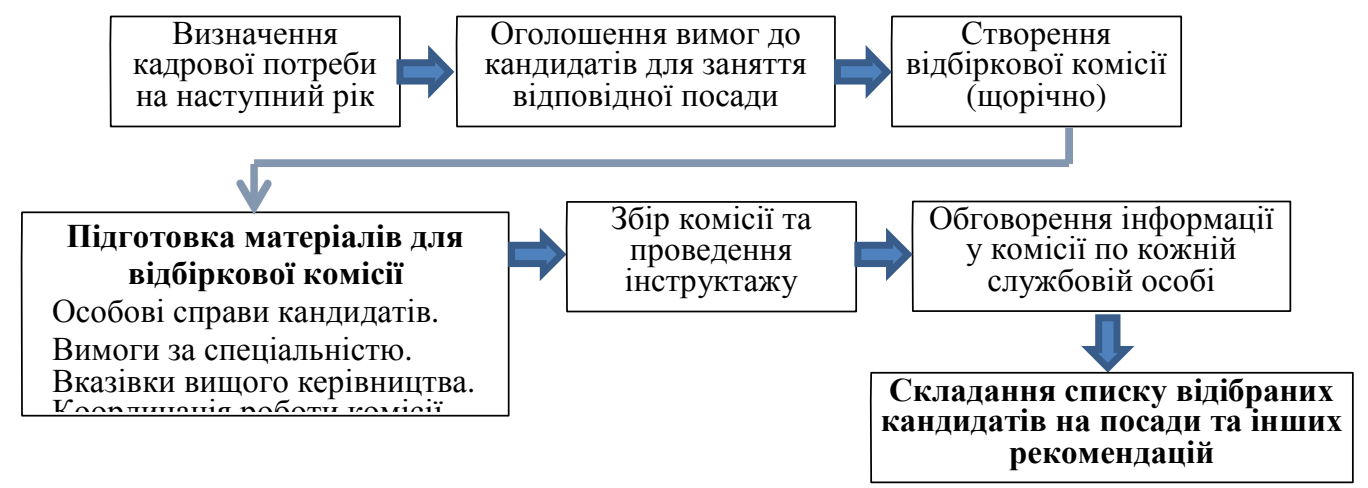

Рис. 6 - Порядок відбору кандидатів для заняття посади

Як приклад, розглянемо склад відбіркової комісії Сухопутних військ США.

Головою комісії призначається посадова особа за військовим званням генерал-лейтенант.

До складу комісії призначається 16 членів комісії, у тому числі: бригадний генерал або генерал-майор; представники бойових підрозділів - 6 (маневрені - 2, вогневі - 1, маневреної підтримки - 2, спецпризначення - 1); представники забезпечення - 4 (логістика - 2, підтримка солдат - 1, корпус MT3 - 1); представники оперативного (бойового) забезпечення - 6.

Основною метою роботи відбіркової комісії $\epsilon$ вибір кандидатів, що підходять для просування по службі найбільшою мірою.

Алгоритм роботи відбіркової комісії представлено на рис. 7.

\begin{tabular}{|c|c|c|c|c|}
\hline $\begin{array}{c}\text { Розгляд i } \\
\text { голосування за } \\
\text { кожну особову } \\
\text { справу кандидата }\end{array}$ & \begin{tabular}{|c|} 
Залагодження \\
відмінностей між \\
членами комісії;
\end{tabular} & $\begin{array}{c}\text { Визначення } \\
\text { відмінностей між } \\
\text { результатами } \\
\text { відбору і вимогами }\end{array}$ & $\begin{array}{c}\text { Складання списку } \\
\text { кандидатів на } \\
\text { посаду за } \\
\text { рейтинговим } \\
\text { принципом }\end{array}$ & $\begin{array}{c}\text { Формування звіту } \\
\text { про роботу } \\
\text { відбіркової комісії }\end{array}$ \\
\hline
\end{tabular}

Рис. 7. Алгоритм роботи відбіркової комісії

Матеріали роботи комісії складаються 3: кореспонденції голові відбіркової комісії (лист офіцера до голови відбіркової комісіі); фотографії офіцера; 
короткого викладу записів про офіцера; інформації про службові результати в особовій картці офіцера (оцінка, освіта та навчання, заохочення, дисциплінарні заходи).

Члени відбіркової комісії зосереджуються на оцінці оцінювачами i старшими оцінювачами (коментарі - винятковий, сильний, слабкий); на адміністративних даних (причина подання, кількість оцінених місяців, інформація ланцюга рейтингування, звіт на який $є$ посилання, назва та опис обов'язків.

Метою оцінювання $є$ усвідомлення даних про службові результати військовослужбовця та визначення даних про його потенціал.

Роль ланцюга рейтингування полягає в тому, щоб чітко і дохідливо донести оцінку кандидата.

У Сухопутних військах США встановлюється система балів. Відносно максимальної кількості балів оцінюються кандидати для просування по службі.

Усі члени комісії оцінюють кожного кандидата за шкалою від 1 до 6:

“6” - винятковий рівень виконання службових обов'язків (обов'язковий до відбору: кращий з кращих);

“5” - відмінний рівень виконання службових обов'язків (має пріоритет до відбору: кращий за більшість кандидатів);

“4” - хороший рівень виконання службових обов'язків (проходить відбір на рівні з іншими кандидатами: достатньо високий рівень);

“3” - посередній рівень виконання службових обов'язків (проходить відбір за наявності потреби: прийнятний рівень);

“2” - низький рівень виконання службових обов'язків (не проходить відбір: не відповідає вимогам для призначення на посаду);

“1” - не прийнятний рівень виконання службових обов'язків (не залишати на службі: не відповідає вимогам для подальшої служби).

За потреби будь-який член комісії може додати до оцінки “+” або “-”, тому “6+” означатиме “найкращий з найкращих" тощо.

Необхідно користуватися цією шкалою як об'єктивним стандартом: порівняння загальної “картини” особової справи офіцера з цим стандартом.

Члени відбіркової комісії використовуючи свої власні судження, оцінюють спочатку особову справу кандидата з урахуванням Меморандуму - інструкції та "словесного портрета".

Як правило, члени відбіркової комісії зосереджують увагу під час оцінювання кандидатів на таких моментах:

коментарі старшого оцінювача;

значки - “галочки”, які ставить старший оцінювач у відповідних “квадратах";

опис обов'язків;

кількість людей, яку прорейтингував старший оцінювач;

коментарі оцінювача і значки - “галочки”, які ставить старший оцінювач у відповідних “квадратах".

Члени відбіркової комісії також уважно дивляться решту особової справи кандидата, особливо якщо в ній є якісь важливі елементи (хороші чи погані). 
Але вони мають повноваження та вказівку застосовувати своє власне судження.

Крім того, членам комісії заборонено консультуватися один з одним (або 3 кимось ще), поки не буде проведено голосування.

Після голосування за скомбінованими балами укладається список кандидатів в порядку якостей, від вищих до нижчих.

Потім саме у цьому списку проводиться розмежувальна лінія між тими, хто повністю підходить, і тими, хто підходить не повністю.

Що необхідно обміркувати кожному члену комісії під час вивчення особових справ кандидатів на посади та голосування:

чи було його рішення простим?;

чи можливо визначити різницю у виконанні службових обов'язків та потенціал різних кандидатів?;

які складові особової справи кандидата вважаєте найважливішими у процесі оцінювання?;

чи вплинули на прийняте рішення якісь фактори?;

яка додаткова інформація могла б допомогти в прийнятті раціонального рішення?;

чи суттєво відрізняються оцінки від середніх оцінок комісії?

Відповіді на зазначені питання в подальшому нададуть допомогу членам комісії з питань прийняття найбільш об'єктивних рішень щодо використання вимог до кандидатів на посади військовослужбовців.

Висновки. Наведений аналіз дозволяє дійти висновку, що порядок підготовки, просування і підвищення кваліфікації офіцерського складу в Збройних силах США, Німеччини, Великобританії, Франції та Ізраїлю передбачає використання приймальних, атестаційних та відбіркових комісій для визначення кандидатів до призначення на офіцерські посади і подальшого просування по службі.

Описана система порядку відбору військовослужбовців для просування по службі заснована на поєднанні керівництва та суджень окремих осіб, що в сукупності дає рекомендований список офіцерів, які підходять для просування по службі найбільшою мірою. Вибір кандидатів грунтується на якостях кандидатів, які оцінюють члени відбіркової комісії 3 використанням комбінованих суджень, що підвищує об'єктивність оцінювання. Система відбору кандидатів забезпечує також відбір для офіцерів, які раніше не були відібрані та у критичній мірі залежить від чесності системи оцінки та процесу роботи відбіркової комісії.

Відбір кандидатів для просування по службі $є$ одним 3 найважливіших елементів стратегічного управління людськими ресурсами i, отже, вимагає пильної уваги стратегічних старших керівників.

Подальші дослідження доцільно зосередити на узагальнені досвіду роботи комісій з відбору кандидатів до призначення на посади у Збройних Силах України за результатами експериментів, які проведено у Командуваннях $\mathrm{CB}, \mathrm{BMC}$, ПС Збройних Сил України та розробленні алгоритму роботи комісії 3 відбору кандидатів до призначення на посади у ЗС України. 


\section{ЛІТЕРАТУРА}

1. Рибидайло А. А., Прокопенко О. С., Терещенко С. А. Концептуальна модель управління кар'єрою військовослужбовців Збройних Сил України. Збірник наукових праџь Центру воєнно-стратегічних досліджень Національного університету оборони України імені Івана Черняховського. Київ - 2020. № 2 (69). - С. 102-109;

2. Стрелецкий А. Система подготовки офицерских кадров в США. Зарубежное военное обозрение. Москва - 2006. №11. - С. 20-27;

3. ROTC Programs - URL: https://www.todaysmilitary.com/education-training/rotc-programs (дата звернення: 10.04.2020);

4. Вильданов М., Ветлугин Р., Сухарева О. Сухопутные войска США: комплектование и подготовка. Национальная оборона. Москва - 2020. №7. - URL: https://oborona.ru/includes/periodics/armedforces/ 2017/0510/143421444/detail.shtml (дата звернення: 27.07.2020);

5. Army Training and Leader Development. Army Regulation 350-1. Headquarters Department of the Army. Washington, DC - 2017. C.- 241;

6. Фильков С. М. Подготовка офицеров резерва в ФРГ. Проблемы подготовки офичерских кадров на военных кафедрах высших учебных заведений: Мат. межвузовской научно-методической конференции 23 мая 2003 года. Москва - 2003. С. 24-27;

7. Румынов Д. Система подготовки офицеров вооружённых сил ФРГ. Зарубежное военное обозрение. Москва - 2014. № 9, С. 24-34;

8. Вооружённые силы Франции: независимость в рамках HATO. - URL: http://opk.com.ua/вооружённые-силы-франции-независимо/ (дата звернення: 12.03.2020);

9. Гацко М. Способы комплектования военнослужащими вооруженных сил иностранных государств. Зарубежное военное обозрение. Москва - 2009. №2, С. 25-31;

10. Шпанчук Г. В. Аналіз систем кадрового менеджменту армій провідних країн світу щодо управління кар'єрою військовослужбовців. Збірник наукових праць Центру воєнностратегічних досліджень Національного університету оборони Украйни імені Івана Черняховського. Київ - 2015. № 1 (53). - С. 122-126;

11. Якупов В. Система комплектования и подготовки кадров вооружённых сил Израиля. Зарубежное военное обозрение. Москва - 2019. №7, С. 29-35;

\section{REFERENCES}

1. Rybydaylo A. A., Prokopenko O. S., Tereshchenko S. A. Kontseptualna model upravlinnya karyeroyu viyskovosluzhbovtsiv Zbroynykh Syl Ukrayiny. Zbirnyk naukovykh prats Tsentru voyenno-stratehichnykh doslidzhen Natsionalnoho universytetu oborony Ukrayiny imeni Ivana Chernyakhovskoho. Kyyiv - 2020. № 2 (69). - S. 102-109.

2. Streletskyy A. Systema podhotovky ofytserskykh kadrov v SSHA. Zarubezhnoe voennoe obozrenye. Moskva - 2006. №11. - S. 20-27.

3. ROTC Programs - URL: https://www.todaysmilitary.com/education-training/rotc-programs (data zvernennya: 10.04.2020).

4. Vyldanov M., Vetluhyn R., Sukhareva O. Sukhoputnye voyska SSHA: komplektovanye y podhotovka. Natsyonalnaya oborona. Moskva - 2020. №7. - URL: https://oborona.ru/includes/periodics/armedforces/ 2017/0510/143421444/detail.shtml (data zvernennya: 27.07.2020).

5. Army Training and Leader Development. Army Regulation 350-1. Headquarters Department of the Army. Washington, DC - 2017. S.- 241.

6. Fylkov S. M. Podhotovka ofytserov rezerva v FRH. Problemy podhotovky ofytserskykh kadrov na voennykh kafedrakh vysshykh uchebnykh zavedenyy: Mat. mezhvuzovskoy nauchnometodycheskoy konferentsyy 23 maya 2003 hoda. Moskva - 2003. S. 24-27.

7. Rumynov D. Systema podhotovky ofytserov vooruzhënnykh syl FRH. Zarubezhnoe voennoe obozrenye. Moskva - 2014. №9, S. 24-34;

8. Vooruzhënnye syly Frantsyy: nezavysymost $v$ ramkakh NATO. - URL: 
http://opk.com.ua/vooruzhënnye-syly-frantsyy-nezavysymo/ (data zvernennya: 12.03.2020).

9. Hatsko M. Sposoby komplektovanyya voennosluzhashchymy vooruzhennykh syl ynostrannykh hosudarstv. Zarubezhnoe voennoe obozrenye. Moskva - 2009. №2, S. 25-31.

10. Shpanchuk H. V. Analiz system kadrovoho menedzhmentu armiy providnykh krayin svitu shchodo upravlinnya karyeroyu viyskovosluzhbovtsiv. Zbirnyk naukovykh prats Tsentru voyennostratehichnykh doslidzhen Natsionalnoho universytetu oborony Ukrayiny imeni Ivana Chernyakhovskoho. Kyyiv - 2015. № 1 (53). - S. 122-126.

11. Yakupov V. Systema komplektovanyya y podhotovky kadrov vooruzhënnykh syl Yzraylya. Zarubezhnoe voennoe obozrenye. Moskva - 2019. №7, S. 29-35.

\title{
РЕЗЮМЕ
}

\author{
Анатолий Рыбыдайло, \\ кандидат технических наук, \\ старший научный сотрудник \\ Татьяна Уварова, \\ кандидат технических наук \\ Сергей Горбачевский, \\ кандидат технических наук, \\ старший научный сотрудник \\ Ірина Цимбал, \\ Андрей Мулявка \\ имени Ивана Черняховского
}

Национальный университет обороны Украины

\section{Анализ опыта работы отборочных комиссий в вооруженных силах стран НАТО и ЕС: задачи, функции и порядок отбора}

Статья посвящена вопросам работы отборочных комиссий в вооруженных силах стран НАТО и ЕС с иелью использования приобретенного опьта для внедрения в практическую деятельность кадровых органов Вооруженных Сил Украины. Приведена общая структура управления человеческими ресурсами, которая применяется в любой армии отдельного государства. В процедурах обучения (повышения квалификации) $u$ продвижения по службе участвуют комиссии (приемные, отборочные, аттестационные), которые формируют определенные рекомендации лицам, принимающим кадровые решения.

Исследован порядок продвижения по службе личного состава государств, входящих в EC и НАТО и проанализированы особенности применения приемных, отборочных, аттестационных комиссий.

Ключевые слова: приемные; аттестационные; отборочные комиссии; менеджмент человеческих ресурсов; стратегическое управление человеческими ресурсами; подготовка $и$ продвижение персонала вооруженных сил.

SUMMARY

Anatolii Rybydajlo,

$\mathrm{PhD}$ (Technical), senior researcher

Tatiana Uvarova,

$\mathrm{PhD}$ (Technical)

Serhii Horbachevsky,

$\mathrm{PhD}$ (Technical), senior researcher 


\section{Irina Tsymbal; Andriy Muliavka}

\section{Analysis of the experience of selection commissions in the armed forces of NATO and EU countries: tasks, functions and procedure for selection}

Introduction. The article is devoted to the work of selection commissions in the armed forces of the NATO and EU countries with the aim of using the acquired experience for the implementation of the personnel bodies of the Armed Forces of Ukraine into practical activities. The general structure of human resource management is given, which is used in any army of a separate state. In the procedures of training (advanced training) and career advancement, commissions (admissions, selection, certification) participate, which form certain recommendations to persons who make personnel decisions.

The order of promotion in the service of the personnel of the EU and NATO states has been investigated and the features of the use of admission, selection, certification commissions have been analyzed.

The purpose of the article is to analyze the procedure for promotion of personnel in the armed forces of EU and NATO member states and the experience of using selection boards in this process to provide sound recommendations for educational and professional development of officers of the Armed Forces of Ukraine.

Methods. To achieve the goal and solve the tasks, it was used a system of the following theoretical research methods: analysis, synthesis, generalization and systematization.

Results. There are three main levels of officer training in the U.S. Armed Forces, which differ in the amount of knowledge and skills an officer must possess after completing a training course at a particular level of training. A similar system of multilevel training exists in England, and in the German Armed Forces the training system has an even more complex multilevel structure.

The Armed Forces of the French Republic have been staffed entirely by volunteers since 2002. Israel has one of the most effective systems of training military personnel, covering all segments of the population, starting from the school desk.

The peculiarities of the work of selection commissions on the example of the US Armed Forces are considered.

Conclusion. The described system of selection of servicemen for promotion is based on a combination of guidance and judgments of individuals, which together gives a recommended list of officers who are suitable for promotion to the greatest extent. The selection of candidates is based on the qualities of the candidates, who are evaluated by the members of the selection committee using a combination of judgments, which increases the objectivity of the evaluation. The selection system also provides selection for officers who have not been previously selected and is critically dependent on the integrity of the evaluation system and the selection process.

Key words: admissions; certification; selection commissions; human resource management; strategic human resource management; training and promotion of military personnel. 